\section{Knowledge about \\ mammography and associated \\ factors: population surveys with \\ female adults and elderly}

\section{Conhecimento sobre mamografia e fatores associados: inquéritos de base populacional com mulheres adultas e idosas}

Ione Jayce Ceola Schneider'

Marui Weber Corseuil'

Antonio Fernando Boing'

Eleonora d'Orsi'

'Postgraduate Program in Collective Health of Universidade Federal de Santa

Catarina - Florianópolis (SC), Brazil.

\section{Abstract}

The purpose of this paper is to describe the knowledge about mammography and to identify associated factors in female adults and elderly. Data were obtained from two population surveys, one with female adults and another with elderlywomen from Florianópolis (SC) in 2009 - 2010. A descriptive analysis of the variables was carried out, the appropriate mean of responses about mammography was estimated and crude and adjusted Poisson regression was conducted to identify associated factors. Among adults, 23.1\% answered all of the questions appropriately and the appropriate average responses was $7.2(95 \%$ CI $7.1-7.3)$ in a total of 9 . In the adjusted model, older age, higher education and income were associated with knowledge about mammography. For the elderly, 15.3\% answered all questions appropriately and the average of appropriate responses was $6.4(95 \%$ CI 5.2 - 6.5) and the factors associated with knowledge about mammography in the adjusted model were younger age groups, increased education and income, and identification of mammography as the main diagnostic method for breast cancer. Information about mammography can neither be transmitted in a clear way nor be easily understood; there are also demographic and socioeconomic differences concerning the knowledge about the exam.

Keywords: Mammography. Knowledge. Early diagnosis. Health surveys. Breast neoplasm. Brazil. 


\section{Resumo}

O objetivo deste estudo é descrever o conhecimento sobre mamografia e identificar os fatores associados em mulheres adultas e idosas. Os dados foram obtidos em dois inquéritos populacionais, um com mulheres adultas $\mathrm{e}$ outro com idosas, na cidade de Florianópolis (SC) em 2009 - 2010. Foi realizada a análise descritiva das variáveis, estimada a média de respostas adequadas do conhecimento sobre mamografia e regressão bruta e ajustada de Poisson para identificar os fatores associados. Entre as adultas, $23,1 \%$ responderam adequadamente todas as questões e a média de repostas adequadas foi 7,2 (IC95\% 7,1 - 7,3) em um total de 9. No modelo ajustado, maior faixa etária, escolaridade e renda foram associados ao conhecimento sobre mamografia. Para as idosas, $15,3 \%$ responderam todas as questões adequadamente, a média de respostas adequadas foi 6,4 (IC95\% 5,2 - 6,5) e os fatores associados ao conhecimento sobre mamografia no modelo ajustado foram faixas etárias menores, aumento da escolaridade e da renda e a identificação da mamografia como principal método diagnóstico do câncer de mama. A informação sobre mamografia pode não estar sendo transmitida de maneira clara e de fácil compreensão, existindo diferenças demográficas e socioeconômicas no conhecimento sobre o exame.

Palavras-chave: Mamografia. Conhecimento. Diagnóstico precoce. Inquéritos epidemiológicos. Neoplasias da mama. Brasil.

\section{Introduction}

Breast cancer is the most prevalent tumor affecting women in the world. For 2008, the appearance of 1.38 million new cases was estimated, and the annual value can surpass 1.78 million in $2020^{1}$. It is estimated that, throughout the world, there are more than 5 million women diagnosed with this tumor in the past 5 years ${ }^{1}$. Even though the survival rate of patients with breast cancer is considered $\mathrm{high}^{2}$, it is one of the main causes of death among women all over the world, being responsible for 458 thousand deaths in 2008 and with the possibility of causing 600 thousand deaths in $2020^{1}$.

In Brazil, approximately 50 thousand cases of breast cancer are diagnosed and about 12 thousand women die every year because of the tumor ${ }^{1}$. After analyzing the mortality rate caused by this cancer, Freitas et al. ${ }^{3}$ demonstrated that it has been stable since 1994. However, Silva et al. ${ }^{4}$ used the correction of this rate by deaths caused by poorly defined causes and showed the tendency of increased mortality between 1980 and 2006, unlike developed countries, which have been presenting reduction since the $1980 \mathrm{~s}^{5}$.

Brazilian public policies demonstrated more emphasis on the control of breast cancer only from 1997 on, with the Program Viva $M u_{l h e r}{ }^{6}$ and, since then, they aim at increasing the mammographic coverage and, consequently, the reduction of mortality caused by breast cancer. The expectation is that the increased mammographic coverage would lead to higher rates of early diagnosis of breast cancer (stages I and II), which would reduce the mortality caused by the disease.

In fact, this diagnostic method has been effective for the early discovery of breast cancer, and it also promotes the reduction of mortality among women aged 50 years old or more ${ }^{7}$. In Brazil, the Consensus of Control for Breast Cancer ${ }^{8}$ points out mammography and clinical examination as tracking methods in the routine of women health care.

Despite the increased access to mammography, in 2009 the coverage of this examination for women aged from 50 to 69 years old living in Brazilian capitals was estimated in $72.2 \%$ in 
the two years prior to the research ${ }^{9}$. Despite the increased coverage of mammography in the past years, there are still both social and geographic difficulties to access the examination ${ }^{9}$.

Besides the difficulties related to access, among the most common reasons why women do not do a mammography are the comprehension that the examination is not necessary and the unawareness as to the importance of the examination for the early diagnosis of breast cancer ${ }^{10,11}$. Studies that assessed the knowledge of women about the early diagnosis of breast cancer demonstrate that they have heard about mammography ${ }^{12,13}$, they know it detects mammary changes ${ }^{12,14}$, but the general knowledge about the test is low ${ }^{12,13}$. Among the knowledge gaps about the examination are: its periodicity ${ }^{15,16}$, the fact that it is useful to track breast cancer, and not only to follow-up pre-existing lesions ${ }^{15}$, and that it is important for early detection ${ }^{17}$, especially at the absence of symptoms ${ }^{11,18,19}$, and the awareness that the mammography can prevent breast cancer ${ }^{14}$.

Women who claim to be well-informed about breast cancer are significantly more adherent to tracking recommendations ${ }^{20}$, however, the fact that women undergo mammography does not imply the knowledge or the understanding about the purpose of the examination ${ }^{21}$. A basic level of knowledge is necessary to implement the specific policies for cancer control ${ }^{12}$. Knowing the level of awareness of women in relation to mammography is important to increase the prevalence of the performance of the examination in the proper periodicity ${ }^{22}$. The awareness about mammography is a little explored subject in literature, and improving it can help the strategies of early diagnosis of breast cancer. This article aims at describing the knowledge about mammography and at identifying the associated factors among women living in Florianópolis, Santa Catarina.

\section{Methods}

in 2009 and 2010 two population surveys were conducted simultaneously and independently in the city of Florianópolis, capital of the State of Santa Catarina, called Adult EpiFloripa and Elderly EpiFloripa, which aimed at studying the health conditions of the adult (20 to 59 years old) and elderly (60 years old or more) population in the city. The estimated population of the city in 2009 was of 408,163 inhabitants; approximately $60 \%$ were adults ( $51.7 \%$ were women) and $10.8 \%$ were elderly ( $57 \%$ of women).

The sample size for the study about the knowledge of mammography and associated factors was calculated independently for each study with the software OpenEpi, Version 2. The considered parameters were: prevalence estimate of $50 \%, 95 \%$ confidence level, sample error of 5 percentage points for female adults and 4.7 for elderly women, design effect of 2 , size of the sample of female adults of 129,035, and of elderly women, 25,616 . Finally, in the survey with the adult women, $10 \%$ were added to compensate for the predicted losses and $20 \%$ for the control of confusion factors; and among the elderly women, $15 \%$ for losses and $20 \%$ for confusion factors. Therefore, the minimum sample was defined with 997 female adults and 1,155 elderly women.

The selection process of the sample was composed of conglomerates in two stages. In the first one, census sectors were systematically sorted out, stratified in deciles according to the monthly mean income of the head of the family and, in the second one, the households. The update of the number of occupied private households was carried out.

In the Adult EpiFloripa, 60 census sectors were sorted out ( 6 per income decile), while in the Elderly EpiFloripa, 80 census sectors were sorted out (8 per income decile). Due to the grouping of census sectors with less than 150 households and the division of those with more than 500 households, by respecting the corresponding income decile and geographic proximity, there were 63 sectors in the study with adults (32.0\% variation coefficient) and 83 sectors in the study with the elderly population (35.2\% variation coefficient). Afterwards, 18 households were systematically sorted out 
in the study with adults, and 64 households in the study with the elderly.

All of the residents of the chosen households, in the age group of each study, were invited to participate. People whose household was visited at least four times were considered as losses. Women who reported the previous diagnosis of breast cancer, those with self-reported skin color being yellow or indigenous and interviews answered by informers were excluded from the analysis.

Data collection was performed by a standardized and pre-tested instrument applied with face to face interviews with the Personal Digital Assistants (PDA). The pilot studies were conducted in sectors that were sorted out for this purpose and were not included in the studies. Data collection of the elderly took place in the second semester of 2009 and in the first semester of 2010, while for the adults it took place in the second semester of 2009.

Data consistency and quality control were weekly verified with the application of a reduced questionnaire by telephone. The reproducibility of the questions presented good to excellent concordance.

In this study, only the concept of awareness was used, from the CAP methodology (knowledge, attitude and practice), characterized as the correct answer to the statements about the use and conduction of mammography ${ }^{13,23}$.

With regard to mammography, nine questions were asked to the interviewed women. If the first questions, "Have you ever heard of a test called mammography?", was answered negatively, the eight following questions were not asked. The answers to these questions were categorized into adequate and inadequate (Table 1). The dependent variable of the study, the awareness about mammography, was built from the sum of adequate answers for the nine questions about mammography, and the value ranged from zero to nine. An adequate knowledge was considered when the woman answered all of the questions correctly.

Table 1 - Questions concerning the knowledge about mammography, Adult and Elderly EpiFloripa surveys, 2009 - 2010. Tabela 1 - Questões sobre conhecimento sobre mamografia, Estudos EpiFloripa Adulto e Idoso, 2009 - 2010.

\begin{tabular}{|c|c|c|}
\hline Questions & Inadequate & Adequate \\
\hline Have you ever heard of an examination called mammography? & No & Right \\
\hline $\begin{array}{l}\text { Mammography is a method to know if there is or there is not } \\
\text { a problem in the breasts }\end{array}$ & $\begin{array}{l}\text { Wrong/Doesn't know/ } \\
\text { NA }\end{array}$ & Right \\
\hline With this examination, the woman can prevent breast cancer & Right/Doesn't Know/NA & Wrong \\
\hline It is only important for women aged more than 50 years old & Right/Doesn't Know/NA & Wrong \\
\hline $\begin{array}{l}\text { It is only important for women who have had a case of } \\
\text { breast cancer in the family }\end{array}$ & Right/Doesn't Know/NA & Wrong \\
\hline $\begin{array}{l}\text { It is an important examination that should be conducted besides } \\
\text { the one made by the doctor and the woman herself }\end{array}$ & $\begin{array}{l}\text { Wrong/Doesn't know/ } \\
\text { NA }\end{array}$ & Right \\
\hline $\begin{array}{l}\text { In mammography, the health professional places the breast of the } \\
\text { woman in a x-ray device, where the breat is pressed, and then } \\
\text { the doctor makes the image }\end{array}$ & $\begin{array}{l}\text { Disagree/Doesn't Know/ } \\
\text { NA }\end{array}$ & Agree \\
\hline $\begin{array}{l}\text { In mammography, the doctors rubs a jelly product on the breast } \\
\text { and, then, with a device on the breast, the doctor follows the images } \\
\text { on a small television screen }\end{array}$ & Agree/Doesn't Know/NA & Disagree \\
\hline $\begin{array}{l}\text { In mammography, the doctor examines the breast of the woman } \\
\text { and delimits a location to stick a thin needle and try to extract some } \\
\text { liquid from inside the breast }\end{array}$ & Agree/Doesn't Know/NA & Disagree \\
\hline
\end{tabular}

Source: Adapted from Marinho ${ }^{13}$. NSA: non applicable.

Fonte: Adaptado de Marinho ${ }^{13}$. NSA: não se aplica. 
Independent variables were: age group (less than 40, 40 - 49, and 50 - 59 years old for the adult women; and $60-69,70-79,80$ years old or more for the elderly women), marital status (with a partner, without a partner), Family per capita income (in income quartiles), schooling ( 0 to 4 years old, 5 to 8,9 to 11,12 or more for the adults, and 0 year, 1 to 4 , 5 to 8,9 to 11 and 12 or more for the elderly), self-reported skin color (white, black, mulatto, yellow skin color and indigenous people were excluded from the analysis because the sample was small), paid job in the last month (yes, no), having a private health insurance plan (yes, no), and identification of mammography as the main test to diagnose breast cancer (yes, no).

Statistical analyses were conducted separately for adult (20 to 59 years old) and elderly women (60 years or more). They were performed in the software STATA/SE 9.0 for Windows (Stata Corp., College Station, United States), considering the complex sample and incorporating sample weights. A descriptive analysis of the questions that compose the variable knowledge about mammography and independent variables was conducted. The mean of the variable knowledge about mammography and its respective confidence interval were described. Since the dependent variable was discreet, the counting model was used with the Poisson regression, both for the crude and the adjusted analyses, in order to estimate the changes in independent variables that affect the conditional mean and the counting probabilities ${ }^{24}$. P value was estimated by the $\mathrm{F}$ test. In the adjusted analysis, the variables that presented $\mathrm{p}<0.20$ in the crude analysis were included one by one in the model; variables that reached $\mathrm{p}<0.05$ and/or adjusted the analysis remained in the model.

Surveys were approved by the Research Ethics Committee of Universidade Federal de Santa Catarina (UFSC), protocol n. 351/08 and 352/2008, adult and elderly, respectively.

\section{Results}

Out of the 959 female adults participating in the survey, 7 were excluded for not answering the block women's health, 13 for having been diagnosed with breast câncer, 15 withyellow skin color and 12 indigenous people, accounting for 914 women (response rate: $91.6 \%$ ). Out of these, approximately $30 \%$ were less than 30 years old, and most reported having white color/ethnicity (86.5\%), 12 schooling years or more (44.1\%), living with a partner (61.1\%), with a job (71.\%) and with a private health insurance plan (60.5\%) (Table2). Most of them (71.0\%) knew that mammographywasthemain methodused to diagnose breast cancer. Among the $29 \%$ who mentioned other diagnostic methods, 185 believed it was the breast self-examination.

Among the adults, $75 \%$ answered up to 8 questions correctly and $23.1 \%$ answered all of them correctly. The mean of adequate responses in relation to the knowledge about mammography was of 7.2 among the adults (95\%CI 7.1 - 7.3). In the adjusted analysis, age group, schooling and income were associated with the knowledge about mammography. The mean of adequate answers of women aged 40 to 49 years old was $14 \%$ higher in relation to women aged 20 - 29 years old. The ones with 12 schooling years or more presented $21 \%$ more adequate responses than the ones with 0 to 4 schooling years. The increased income quartile promoted the increased mean of adequate responses in comparison to the first quartile (Table 2).

The description of questions that formed the variable knowledge about mammography is in Table 3. It was observed that $97.3 \%$ of the adult women had heard of mammography; approximately $95 \%$ answered adequately that the examination identifies breast-related problems. Thequestion with thelowerpercentage of adequate answers was the one about mammography preventing breast cancer, since only $48.7 \%$ recognized the statement as being correct.

Among the 1,089 participating elderly women, 32 were excluded for interviews that were answered by informers, 35 for not answering the questions related to women's health, 29 who were diagnosed with cancer, 7 indigenous participants and 7 with yellow skin color; therefore, 985 elderly women participated in this study (response rate: $85.3 \%$ ). Elderly women were mostly 60 to 69 years old $(49.6 \%)$, 
Table 2 - Univariate analysis and bivariate analysis, crude and adjusted regression about the knowledge of mammography for adult women. Florianópolis, 2010.

Tabela 2 - Análise univariada, bivariada, regressão bruta e ajustada do conhecimento sobre mamografia para mulheres adultas. Florianópolis, 2010.

\begin{tabular}{|c|c|c|c|c|c|}
\hline Variables & n (\%) & $\begin{array}{l}\text { Mean of adequate } \\
\text { responses }(95 \% \mathrm{Cl})\end{array}$ & $\begin{array}{l}\text { Crude analysis } \\
\qquad(95 \% \mathrm{Cl})\end{array}$ & $\begin{array}{l}\text { p-value } \\
\text { (F test) }\end{array}$ & $\begin{array}{l}\text { Adjusted analysis } \\
\qquad(95 \% \mathrm{Cl})\end{array}$ \\
\hline \multicolumn{6}{|l|}{ Age Group ( $n=914$ ) } \\
\hline $20-29$ & $272(29.8)$ & $6.87(6.56-7.19)$ & 1.00 & \multirow[t]{4}{*}{$<0.001$} & 1.00 \\
\hline $30-39$ & $209(22.9)$ & $7.03(6.54-7.52)$ & $1.02(0.96-1.09)$ & & $1.03(0.98-1.08)$ \\
\hline $40-49$ & $248(27.1)$ & $7.70(7.48-7.92)$ & $1.12(1.08-1.16)$ & & $1.14(1.10-1.19)$ \\
\hline $50-59$ & $185(20.2)$ & $7.20(6.87-7.54)$ & $1.05(1.00-1.10)$ & & $1.10(1.04-1.16)$ \\
\hline \multicolumn{6}{|l|}{ Skin color $(n=910)$} \\
\hline Black & $52(5.7)$ & $6.58(6.21-6.95)$ & 1.00 & \multirow[t]{3}{*}{0.013} & \multirow[t]{3}{*}{ * } \\
\hline White & $787(86.5)$ & $7.21(6.90-7.52)$ & $1.10(1.03-1.17)$ & & \\
\hline Mulatto & $71(7.8)$ & $7.31(6.97-7.64)$ & $1.11(1.03-1.20)$ & & \\
\hline \multicolumn{6}{|c|}{$\begin{array}{l}\text { Schooling in years of study } \\
(\mathrm{n}=913)\end{array}$} \\
\hline 0 to 4 years & $83(9.1)$ & $6.29(5.70-6.87)$ & 1.00 & \multirow[t]{4}{*}{$<0.001$} & 1.00 \\
\hline 5 to 8 years & $139(15.2)$ & $5.82(5.12-6.52)$ & $0.93(0.85-1.01)$ & & $0.94(0.87-1.01)$ \\
\hline 9 to 11 years & $287(31.4)$ & $7.26(6.98-7.53)$ & $1.15(1.07-1.24)$ & & $1.17(1.08-1.26)$ \\
\hline 12 years old or more & $404(44.1)$ & $7.73(7.56-7.91)$ & $1.23(1.12-1.35)$ & & $1.22(1.11-1.34)$ \\
\hline \multicolumn{6}{|l|}{ Marital status $(n=914)$} \\
\hline With partner & $558(61.1)$ & $7.18(6.85-7.52)$ & 1.00 & \multirow[t]{2}{*}{0.859} & \\
\hline Without partner & $356(38.9)$ & $7.20(6.95-7.45)$ & $1.00(0.97-1.04)$ & & \\
\hline \multicolumn{6}{|c|}{ Income in quartiles $(n=898)$} \\
\hline $1^{\text {st }}$ Quartile & $241(26.8)$ & $6.28(5.77-6.79)$ & 1.00 & \multirow[t]{4}{*}{$<0.001$} & 1.00 \\
\hline $2^{\text {nd }}$ Quartile & $225(25.1)$ & $7.14(6.83-7.46)$ & $1.24(1.06-1.22)$ & & $1.08(1.02-1.15)$ \\
\hline $3^{\text {rd }}$ Quartile & $219(24.4)$ & $7.49(7.28-7.72)$ & $1.19(1.11-1.28)$ & & $1.09(1.03-1.15)$ \\
\hline $4^{\text {th }}$ Quartile & $213(23.7)$ & $7.89(7.64-8.13)$ & $1.26(1.16-1.37)$ & & $1.11(1.04-1.19)$ \\
\hline \multicolumn{6}{|l|}{ Current job $(n=914)$} \\
\hline Yes & $655(71.6)$ & $6.97(6.61-7.34)$ & 1.00 & \multirow[t]{2}{*}{0.030} & \multirow[t]{2}{*}{ * } \\
\hline No & $259(28.4)$ & $7.28(7.00-7.55)$ & $1.04(1.00-1.08)$ & & \\
\hline \multicolumn{6}{|c|}{ Health insurance $(n=912)$} \\
\hline No & $360(39.5)$ & $6.65(6.19-7.11)$ & 1.00 & \multirow[t]{2}{*}{$<0.001$} & \multirow[t]{2}{*}{ * } \\
\hline Yes & $552(60.5)$ & $7.54(7.35-7.73)$ & $1.13(1.07-1.20)$ & & \\
\hline \multicolumn{6}{|c|}{$\begin{array}{l}\text { Mammography as the main method to } \\
\text { diagnose breast cancer }(n=914)\end{array}$} \\
\hline No & $265(29.0)$ & $7.14(6.70-7.59)$ & 1.00 & \multirow[t]{2}{*}{0.694} & \multirow[t]{2}{*}{-} \\
\hline Yes & 649 (71.0) & $7.21(6.96-7.46)$ & $1.01(0.96-1.05)$ & & \\
\hline
\end{tabular}

*Without significance in adjusted model.

*Sem significância no modelo ajustado. 
reported having white color/ethnicity (87.4\%), with 1 to 4 schoolingyears (36.3\%), living without a partner (54.3\%), with private health insurance plan (63.7\%), and without a paid job at the time of the interview (90.4\%). Mammography was identified as the main method to diagnose breast cancer by $75.9 \%$ of the participants, butamongthe ones who did not mention this method (24.1\%), 114 claimed that the breast self-examination was the most adequate method (Table 3 ).

Among the elderly, $75 \%$ answered up to 8 questions correctly, and $15.3 \%$ answered all of the questions adequately. The mean of adequate responses in the questions concerning the knowledge about mammography was of $6.4 \%(95 \%$ CI $5.2-6.5)$. In the adjusted analysis, age group, schooling, income quartiles and the main method to diagnose breast cancer were factors independent of knowledge. Belonging to the age groups of 60 to 69 years old and 70 to 79 years old has been associated with the higher mean of adequate responses in comparison to women aged 80 years old or more. The increased schooling was associated to the increased adequate answers in relation to knowledge, as well as the higher income. The mean of adequate responses among those that identified mammography as the main method to diagnose breast cancer was $19 \%$ higher than for those who reported other methods (Table 4).

With regard to the questions that composed the knowledge about mammography (Table 3), most elderly women had heard of the examination (96.5\%) and they knew it identifies breast-related problems (90.6\%). The lowest percentage of adequate responses was found in the question about mammography preventing breast cancer, since only $31.5 \%$ of the participants answered this statement was incorrect. About the importance of mammography, $72.6 \%$ adequately considered that it is useful for women aged less than 50 years old; $79.3 \%$ claimed it is only not indicated for women with family history of cancer, and $78.1 \%$ responded correctly that, besides the clinical examination of the breast, the selfexamination is also important.

Tabela 3 - Frequência de respostas adequadas para cada questão relativa ao conhecimento sobre mamografia entre mulheres adultas e idosas. Florianópolis, 2009 - 2010.

Table 3 - Frequency of appropriate responses to each question about knowledge of mammography among adults and elderly women. Florianópolis, 2009- 2010.

\begin{tabular}{|c|c|c|c|c|}
\hline \multirow{2}{*}{ Questions } & \multicolumn{2}{|c|}{ Adults } & \multicolumn{2}{|c|}{ Eldery } \\
\hline & n (\%) & $95 \% \mathrm{Cl}$ & n (\%) & $95 \% \mathrm{Cl}$ \\
\hline Have you ever heard of mammography? & $893(97.3)$ & $95.0-99.5$ & $950(96.5)$ & $95.2-97.9$ \\
\hline $\begin{array}{l}\text { Is mammography a way to know if there is or is not a } \\
\text { problem in the breast }\end{array}$ & $868(94.9)$ & $92.3-97.5$ & $889(90.6)$ & $88.5-92.7$ \\
\hline With this examination, will the woman prevent breast cancer & $435(48.7)$ & $43.5-53.8$ & $303(31.5)$ & $26.3-36.7$ \\
\hline It is only important for women aged 50 years old or more & $829(90.5)$ & $87.3-93.6$ & $702(72.6)$ & $67.3-77.9$ \\
\hline $\begin{array}{l}\text { It is only important for women with cases of breast cancer } \\
\text { in the family }\end{array}$ & $849(93.0)$ & $89.5-96.5$ & $773(79.3)$ & $76.1-82.5$ \\
\hline $\begin{array}{l}\text { It is an important examination that should be conducted besides } \\
\text { the one made by the doctor and by the woman herself }\end{array}$ & $865(94.1)$ & $91.3-96.9$ & $783(78.1)$ & $70.7-85.5$ \\
\hline $\begin{array}{l}\text { In mammography, the health professional places the breast of } \\
\text { the woman in a x-ray device, where the breat is pressed, } \\
\text { and then the doctor makes the image }\end{array}$ & $750(81.2)$ & $78.1-84.3$ & $854(87.5)$ & $85.0-89.9)$ \\
\hline $\begin{array}{l}\text { In mammography, the doctors rubs a jelly product on the breast } \\
\text { and, then, with a device on the breast, the doctor follows the } \\
\text { images on a small television screen }\end{array}$ & $474(51.7)$ & $45.4-58.0$ & $465(44.9)$ & $37.8-52.0$ \\
\hline $\begin{array}{l}\text { In mammography, the doctor examines the breast of the } \\
\text { woman and delimits a location to stick a thin needle and try } \\
\text { to extract some liquid from inside the breast }\end{array}$ & $613(67.8)$ & $61.4-74.2$ & $574(55.4)$ & $47.4-63.4$ \\
\hline Total of correct answers (9 adequate responses) & $211(23.1)$ & $20.3-25.8$ & $150(15.2)$ & $13.0-17.5$ \\
\hline
\end{tabular}


Table 4 - Univariate analysis and bivariate analysis, crude and adjusted regression about the knowledge of mammography for elderly women. Florianópolis, 2009-2010.

Tabela 4 - Análise univariada, bivariada, regressão bruta e ajustada do conhecimento sobre mamografia para mulheres idosas. Florianópolis, 2009-2010.

\begin{tabular}{|c|c|c|c|c|c|}
\hline Variables & n (\%) & $\begin{array}{l}\text { Mean of adequate } \\
\text { responses }(95 \% \mathrm{Cl})\end{array}$ & $\begin{array}{c}\text { Crude analysis } \\
(95 \% \mathrm{Cl})\end{array}$ & $\begin{array}{l}\text { p-value } \\
\text { (F test) }\end{array}$ & $\begin{array}{c}\text { Adjusted analysis } \\
(95 \% \mathrm{Cl})\end{array}$ \\
\hline \multicolumn{6}{|l|}{ Age group $(n=985)$} \\
\hline 80 years old or more & $127(12.9)$ & $4.81(4.14-5.48)$ & 1.00 & \multirow[t]{3}{*}{$<0.001$} & 1.00 \\
\hline 70 to 79 years old & $369(37.5)$ & $6.34(6.01-6.68)$ & $1.32(1.16-1.50)$ & & $1.25(1.10-1.41)$ \\
\hline 60 to 69 years old & $489(49.6)$ & $6.78(6.53-7.03)$ & $1.41(1.23-1.62)$ & & $1.30(1.14-1.48)$ \\
\hline \multicolumn{6}{|l|}{$\begin{array}{l}\text { Self-reported skin color } \\
(n=984)\end{array}$} \\
\hline Black & $45(4.6)$ & $5.97(4.76-7.17)$ & 1.00 & \multirow[t]{3}{*}{0.619} & \\
\hline Mulatto & $79(8.0)$ & $6.20(5.71-6.69)$ & $1.04(0.84-1.28)$ & & \\
\hline White & $860(87.4)$ & $6.41(6.15-6.69)$ & $1.07(0.87-1.32)$ & & \\
\hline \multicolumn{6}{|l|}{$\begin{array}{l}\text { Schooling in years } \\
\text { of stude }=y(n=981)\end{array}$} \\
\hline Illiterate & $95(9.7)$ & $4.86(4.36-5.37)$ & 1.00 & \multirow[t]{5}{*}{$<0.001$} & 1.00 \\
\hline 1 to 4 years & $356(36.3)$ & $5.88(5.46-6.30)$ & $1.21(1.07-1.36)$ & & $1.13(1.01-1.28)$ \\
\hline 5 to 8 years & $206(21.0)$ & $6.70(6.37-7.03)$ & $1.38(1.24-1.53)$ & & $1.26(1.13-1.40)$ \\
\hline 9 to 11 years & $147(15.0)$ & $6.65(6.20-7.10)$ & $1.37(1.20-1.56)$ & & $1.26(1.10-1.44)$ \\
\hline 12 years or more & $177(18.0)$ & $7.31(7.01-7.60)$ & $1.50(1.35-1.68)$ & & $1.34(1.19-1.52)$ \\
\hline \multicolumn{6}{|c|}{ Income in quartiles $(n=985)$} \\
\hline $1^{\text {st }}$ Quartile & $270(27.4)$ & $5.98(5.58-6.37)$ & 1.00 & \multirow[t]{4}{*}{$<0.001$} & 1.00 \\
\hline $2^{\text {nd }}$ Quartile & $258(26.2)$ & $5.94(5.56-6.33)$ & $0.99(0.93-1.06)$ & & $1.00(0.94-1.06)$ \\
\hline $3^{\text {rd }}$ Quartile & $235(23.9)$ & $6.69(6.34-7.05)$ & $1.12(1.03-1.22)$ & & $1.09(1.01-1.18)$ \\
\hline $4^{\text {th }}$ Quartile & $222(22.5)$ & $6.91(6.58-7.24)$ & $1.16(1.07-1.24)$ & & $1.07(1.01-1.15)$ \\
\hline \multicolumn{6}{|l|}{ Marital status $(n=985)$} \\
\hline Without a partner & $535(54.3)$ & $6.08(5.79-6.38)$ & 1.00 & \multirow[t]{2}{*}{$<0.001$} & \multirow[t]{2}{*}{ * } \\
\hline With a partner & $450(45.7)$ & $6.71(6.41-7.00)$ & $1.10(1.05-1.16)$ & & \\
\hline \multicolumn{6}{|c|}{ Health insurance $(n=985)$} \\
\hline No & $358(36.3)$ & $5.85(5.45-6.25)$ & 1.00 & \multirow[t]{2}{*}{$<0.001$} & * \\
\hline Yes & $627(63.7)$ & $6.63(6.39-6.88)$ & $1.13(1.06-1.21)$ & & \\
\hline \multicolumn{6}{|l|}{$\begin{array}{l}\text { Current paid job } \\
(\mathrm{n}=985)\end{array}$} \\
\hline No & $890(90.4)$ & $6.34(6.10-6.59)$ & 1.00 & \multirow[t]{2}{*}{0.279} & \\
\hline Yes & $95(9.6)$ & $6.58(6.06-7.10)$ & $1.04(0.97-1.11)$ & & \\
\hline \multicolumn{6}{|c|}{$\begin{array}{l}\text { Mammography as the main } \\
\text { method to diagnose breast } \\
\text { cancer }(n=923)\end{array}$} \\
\hline No & $237(24.1)$ & $5.38(4.94-5.81)$ & 1.00 & \multirow[t]{2}{*}{0.011} & 1.00 \\
\hline Yes & $748(75.9)$ & $6.67(6.38-6.95)$ & $1.24(1.13-1.36)$ & & $1.19(1.10-1.29)$ \\
\hline
\end{tabular}




\section{Discussion}

This study enabled to explore the knowledge about mammography and the associated factors both in adult and elderly women. Out of the 9 questions about knowledge, the adult women answered an average of 7.2 questions correctly, and the elderlywomen, 6.4. Women aged between 40 and 59 years old among the adults and 60 to 79 years old among the elderly presented more knowledge and, in both groups, also those with 8 schooling years or more and with higher per capita income. Among the elderly participants, besides these factors, identifying mammography as the main method to diagnose breast cancer has also been associated with knowledge.

Marinho et al. ${ }^{23}$ studied the knowledge about mammography among women aged more than 40 years old who were users of public health services in Campinas (SP), and found that only $7.4 \%$ answered all of the questions adequately. In this study, with a similar questionnaire, $23.1 \%$ of the adult women and $15.3 \%$ of the elderly women answered all of the questions correctly. In the study by Brito et al. ${ }^{12}$, conducted in São Luís (MA), the percentage of adequate knowledge was of $24 \%$, considered low by the authors. Even though these studies presented different methodologies, whichlimit direct comparisons, the percentage found in in this study is higher than the one from Campinas (SP) and lower than the one from São Luís (MA)

The study by Brito et al. ${ }^{12}$ also found an association between schooling with the knowledge about mammography, in which women with higher educational level had 50\% more chances of presenting adequate knowledge. In Malaysia, besides the increased educational level, the higher income was also associated with knowledge, and women aged 50 to 59 years old had $50 \%$ more chances of having adequate knowledge in comparison to those aged 60 years old or more ${ }^{19}$. A study by Amin et al. ${ }^{15}$, in Saudi Arabia, showed that besides educational level, having a family history of breast cancer, having a job and being exposed to breast clinical examinations were factors associated with the increased level of knowledge ${ }^{15}$. The study by Marinho et al. ${ }^{23}$ did not find any association with sociodemographic factors. This study was developed with a sample of low income and low schooling women, in a public service of Campinas (SP), which limits direct comparisons with this study.

The knowledge about the importance of mammography and who should be able to perform it can influence women in the adherence to tracking. In this study, the percentage of women who have heard of mammography was similar to that found in the study conducted in the Northeast of Brazil $(91.9 \%)^{12}$ and in health services of Campinas (SP) $(93.5 \%)^{23}$. In relation to the use of mammography, in this study most of the participants knew it can identify breast-related issues, while in the study by Brito et al. ${ }^{12}, 78.1 \%$ knew that the examination was used to identify neoplastic lesions in the breast. In Brazil, more than half of the women aged 40 to 69 years old have had a mammography at least once ${ }^{9}$. Takechi ${ }^{25}$ claims that the efficacy of the examination is usually recognized by those who have undergone it.

Mammography was identified by more than $70 \%$ of the women, both adults and elderly, as the main method to diagnose breast cancer and, among the elderly, it has been associated to the knowledge about the examination. The percentage of recognition was high when compared to women living in Australia; despite the free offer of mammography for women aged 40 years old or more in that country, only $29.1 \%$ of the interviewees recognized mammography as a method to diagnose breast cancer, pointing out to the need for clarifications for the population ${ }^{26}$.

In relation to the other methods apart from mammography as the main forms of diagnosing breast cancer, the most frequent one was the breast self-examination, mentioned by approximately $11 \%$ of the elderly women and $20 \%$ of the adult women. Sim et al. ${ }^{19}$ showed that there is insufficient understanding among Asian women about the risk factors and errors in relation to tracking and treatment of breast cancer. Between the findings of the study, $27 \%$ of the people think that if the breast self-examination is normal, there is no need for mammography. In the study by Santos et al. ${ }^{27}$ conducted with elderly women from the community centers of São 
Paulo, 29.7\% answered that the breast selfexamination is the main method to diagnose breast cancer. These findings can be due to the obsolete recommendation of this method is the adequate one for the early detection of breast cancer for more than 70 yeras $^{28}$.

Still, there are issues about mammography that are unknown by the women. One of them is that mammography prevents breast cancer, since in this study it was observed that only $48.7 \%$ of the adult women and $31.5 \%$ of the elderly women answered this statement adequately, as being incorrect. This was also pointed out by Webster and Austoker ${ }^{14}$, who showed that $94 \%$ of the women correctly answered that mammographic tracking leads to the early detection, but $45 \%$ believed that mammography prevents breast cancer. Believing that mammography prevents breast cancer can lead women to ignore the symptoms in the interval between examinations, which restates the need to inform about the importance of mammography as a diagnostic method.

Another question to be enlightened is that many women think that mammography is only important for those with a Family history of breast cancer. This wrong comprehension can have a negative influence on the practice of mammography, since they interpret that they have low risk of being diagnosed with breast cancer ${ }^{10}$ only because there is no family history. Even though women with family history of cancer have more chances of progressing with the disease ${ }^{29}$, only $5 \%$ to $10 \%$ of the cases occur among these women ${ }^{30}$.

In relation to the factors associated with knowledge, the age groups that are the focus of mammographic tracking - adults aged from 40 to 59 years old and elderly women aged 60 to 69 years old — had significantly higher mean of adequate answers. The importance of age can be mainly observed in the group of young women, for which the information should be publicized and clarified concerning the diagnosis of breast cancer. This way, when they become part of the priority age groups for tracking, they will be informed enough to see a doctor and undergo routine examinations; if they are diagnosed early, it leads to reduced mortality.

Women aged from 40 to 49 years old presented more average of knowledge about mammography, regardless of income and schooling, which is in accordance with the findings by Amim et al. ${ }^{15}$. They are the most well-informed ones, despite the divergences found in the age for the beginning of tracking by mammography. In Brazil, The Consensus of Control for Breast Cancer ${ }^{8}$ states that tracking mammography in women without family history of breast cancer should only be conducted in women aged more than 50 years old. However, the promulgation of Law 11.664, in 2008, ensures the performance of mammography from the age of 40, but it does not mention tracking among women aged 40 to 49 years old. The tracking in these women, according to the Consensus ${ }^{8}$, should be conducted by the clinical examination of the breast, but $67 \%$ of them had already had a mammography ${ }^{9}$ and represent more than $20 \%{ }^{31}$ of the breast cancer diagnoses. It is known that, after participating in the mammographic tracking, they present with significant reduction of mortality, similarly to women aged 50 to 59 years old; however, the first ones present the highest rates of false-positive tests and the need for additional imaging examinations?

The findings referring to the association of low schooling and the reduction of knowledge about cancer ${ }^{14,32}$ and early diagnosis ${ }^{12,15,19}$, as well as low income ${ }^{19}$, also shown in this study, suggest that the lack of knowledge in these groups can be a result of inadequate educational material ${ }^{19}$, making them incomprehensible, which shows important social inequities in the access to information concerning the early diagnosis of breast cancer.

Studies show that the printed and television media are the main source of information for women ${ }^{12,19,20,27,32,33}$. In national studies, Brito et al. ${ }^{12}$ demonstrated that the media was the second source of information about mammography (17.1\%), and Santos et al. ${ }^{27}$ showed they were the third main source of information (10.9\%). However, in international studies $^{19,20,32,33}$, more than $50 \%$ of the women mention the means of communication 
as the main source of information. The way the media transmits the information about the early diagnosis can be incomprehensible; even though the central theme is clear, the questions related to it are not ${ }^{25}$. Among the campaigns of early diagnoses publicized in some of the main newspapers and magazines in Brazil between June 2006 and July 2007, more than $80 \%$ were about breast cancer, with the objective of raising awareness of the population about the subject ${ }^{34}$. This can be the reason why women with low income and schooling present lower rates of adequate answers. Many of the campaign materials are printed, and there is high percentage of women with less than eight schooling years - and they may not understand or have access to the information in this type of publication.

Health professionals are also mentioned as important sources of information about can$\operatorname{cer}^{12,20,27,32,33}$. Together with the media, they can explain these questions to the women, such as mammography preventing breast cancer and its importance regardless of the family history of cancer, and to encourage them to undergo tracking examinations. Women who attended educational interventions about breast cancer and tracking have significantly increased knowledge, and also significant reduction in the barriers to undergo mammography ${ }^{35}$.

Besides, according to the World Health Organization $^{36}$, social mobilization assists the planning and implementation of cancer control actions. Campaigns about the importance of mammography, together with the government, the civil society, and groups of patients and the community can lead to the increased knowledge about the examination.

Theeffectivecommunication between health professionals and the women, with the help of media campaigns, can ensure that the woman has access to knowledge about the importance of mammography as a routine examination, regardless of risk factors or symptoms, so she can feel motivated to do it and have access to it in the proper periodicity. Therefore, the improved knowledge is expected, thus reducing one of the barriers for the early diagnosis of breast cancer.

In this study, despite the control of confusion factors, by means of the adjusted analysis, there might be some residual confusion due to the impossibility of controlling all of the relations that contribute with knowledge, such as knowing someone with breast cancer, having family history of breast cancer or attending places with specific information about diagnosis, such as routine appointments with gynecologists and mastologists. Besides, the lack of a standardized instrument to assess the knowledge about breast cancer, early diagnosis and risk factors prevents direct comparisons between the findings in this study and other analyses. Among the positive aspects of this study, population range, high response rate and the identification of factors associated with the knowledge about mammography by the population-based study stand out.

\section{Conclusion}

Finally, this article approached the knowledge about mammography and pointed out that it is influenced by the age groups of the women and the increase income and schooling. It is suggested that the information about the importance of mammography publicized by the media and health professionals should be clear and easy to understand, thus ensuring adequate knowledge to all of the women. More population-based studies can help to clarify the knowledge about mammography as a barrier for the early diagnosis of breast cancer. 


\section{References}

1. Ferlay J, Shin HR, Bray F, Forman D, Mathers C, Parkin DM. GLOBOCAN 2008, Cancer Incidence and Mortality Worldwide: IARC CancerBase No. 10. [Internet] Lyon, France: International Agency for Research on Cancer; 2010. Disponível em: http:// globocan.iarc.fr. (Acessado em 26 de março de 2011).

2. Coleman MP, Quaresma M, Berrino F, Lutz JM, De Angelis R, Capocaccia R, et al. Cancer survival in five continents: a worldwide population-based study (CONCORD). Lancet Oncol 2008; 9(8): 730-56.

3. Freitas-Junior R, Gonzaga CM, Freitas NM, Martins E, Dardes Rde C. Disparities in female breast cancer mortality rates in Brazil between 1980 and 2009. Clinics (Sao Paulo) 2012; 67(7): 731-7.

4. Silva GA, Gamarra CJ, Girianelli VR, Valente JG. Cancer mortality trends in Brazilian state capitals and other municipalities between 1980 and 2006. Rev Saúde Pública 2011; 45(6): 1009-18.

5. Coleman MP, Forman D, Bryant H, Butler J, Rachet B, Maringe C, et al. Cancer survival in Australia, Canada, Denmark, Norway, Sweden, and the UK, 1995-2007 (the International Cancer Benchmarking Partnership): an analysis of population-based cancer registry data. Lancet 2011; 377(9760): 127-38.

6. Instituto Nacional de Câncer (Brasil). Viva Mulher. Câncer de Colo de Útero: informações técnico-gerenciais e ações desenvolvidas. INCA: 2002. Disponivel em: http://bvsms. saude.gov.br/bvs/publicacoes/viva_mulher.pdf. (Acessado em 17 de novembro de 2008).

7. Nelson HD, Tyne K, Naik A, Bougatsos C, Chan BK, Humphrey L. Screening for breast cancer: an update for the U.S. Preventive Services Task Force. Ann Intern Med 2009; 151(10): 727-37, W237-42.

8. Ministério da Saúde (Brasil). Controle do Câncer de Mama - Documento de Consenso. INCA: 2004. Disponivel em: http://www.inca.gov.br/publicacoes/Consensointegra.pdf. (Acessado em 20 de abril de 2007).

9. Oliveira EX, Pinheiro RS, Melo EC, Carvalho MS. Condicionantes socioeconômicos e geográficos do acesso a mamografia no Brasil, 2003-2008. Ciên Saúde Colet 2011; 16(9): 3649-64.

10. Gierisch JM, O'Neill SC, Rimer BK, DeFrank JT, Bowling JM, Skinner CS. Factors associated with annual-interval mammography for women in their 40s. Cancer Epidemiol 2009; 33(1): 72-8.

11. Parsa P, Kandiah M. Predictors of adherence to clinical breast examination and mammography screening among Malaysian women. Asian Pac J Cancer Prev 2010; 11(3): 681-8.

12. Brito LG, Brito LM, Chein MB. Knowledge about mammography of women from a Northeastern city in Brazil. Prev Med 201; 52(3-4): 285-6.

13. Marinho LAB. Conhecimento, atitude e prática do auto exame da mama e do exame de mamografia em usuárias dos centros de saúde do município de Campinas [tese de doutirado]. Campinas: Universidade Estadual de Campinas; 2001.
14. Webster P, Austoker J. Women's knowledge about breast cancer risk and their views of the purpose and implications of breast screening--a questionnaire survey. J Public Health (Oxf) 2006; 28(3): 197-202.

15. Amin TT, Al Mulhim AR, Al Meqihwi A. Breast cancer knowledge, risk factors and screening among adult Saudi women in a primary health care setting. Asian Pac J Cancer Prev 2009; 10(1): 133-8.

16. Anagnostopoulos F, Dimitrakaki C, Fitzsimmons D, Potamianos G, Niakas D, Tountas Y. Health beliefs and illness perceptions as related to mammography uptake in randomly selected women in Greece. J Clin Psychol Med Settings 2012; 19(2): 147-64.

17. Akhigbe AO, Omuemu VO. Knowledge, attitudes and practice of breast cancer screening among female health workers in a Nigerian urban city. BMC Cancer 2009; 9: 203.

18. Ogedegbe G, Cassells AN, Robinson CM, DuHamel K, Tobin JN, Sox CH, et al. Perceptions of barriers and facilitators of cancer early detection among low-income minority women in community health centers. J Natl Med Assoc 2005; 97(2): 162-70.

19. Sim HL, Seah M, Tan SM. Breast cancer knowledge and screening practices: a survey of 1,000 Asian women. Singapore Med J 2009; 50(2): 132-8.

20. Sadler GR, Ko CM, Cohn JA, White M, Weldon RN, Wu P. Breast cancer knowledge, attitudes, and screening behaviors among African American women: the Black cosmetologists promoting health program. BMC Public Health 2007; 7: 57.

21. Webster TF, Hoffman K, Weinberg J, Vieira V, Aschengrau A. Community- and individual-level socioeconomic status and breast cancer risk: multilevel modeling on Cape Cod, Massachusetts. Environ Health Perspect 2008; 116(8): 1125-9.

22. Williams KP, Mabiso A, Todem D, Hammad A, Hill-Ashford $\mathrm{Y}$, Hamade $\mathrm{H}$, et al. Differences in knowledge of breast cancer screening among African American, Arab American, and Latina women. Prev Chronic Dis 2011; 8(1): A20.

23. Marinho LAB, Cecatti JG, Osis MJ, Gurgel MS. Knowledge, attitude and practice of mammography among women users of public health services. Rev Saúde Pública 2008; 42(2): 200-7.

24. Long JS, Freese J. Regression models for categorical dependent variables using Stata. Texas (USA): Stata Press, College Sation; 2003.

25. Takechi M. Construction of knowledge and perception of mammography in the UK. Ecancer 2008; 2: 98.

26. Villanueva EV, Jones S, Nehill C, Favelle S, Steel D, Iverson D, et al. The 2003 Australian Breast Health Survey: survey design and preliminary results. BMC Public Health 2008; 8: 13.

27. Santos GD, Chubaci RY. O conhecimento sobre o câncer de mama e a mamografia das mulheres idosas frequentadoras de centros de convivência em São Paulo (SP, Brasil). Ciên Saúde Colet 2011; 16(5): 2533-40. 
28. International Agency for Research on Cancer (IARC). Breast Cancer Screening. IARC: 2002. Disponivel em: http://www. iarc.fr/en/publications/pdfs-online/prev/handbook7/ Handbook7_Breast.pdf. (Acessado em 10 de abril de 2011).

29. McPherson K, Steel CM, Dixon JM. ABC of breast diseases. Breast cancer-epidemiology, risk factors, and genetics. BMJ 2000; 321(7261): 624-8.

30. National Cancer Institute. Genetics of Breast and OvarianCancer (PDQ). [Internet] 2012 [última modificação 17 de fevereiro de 2012]; Disponível em: http://www.cancer. gov/cancertopics/pdq/genetics/breast-and-ovarian/ healthprofessional.

31. Martins E, Freitas-Junior R, Curado MP, Freitas NMA, Oliveira JC, Silva CMB. Evolução temporal dos estádios do câncer de mama ao diagnóstico em um registro de base populacional no Brasil central. Rev Bras Ginecol Obstet 2009; 31(5): 219-23.

32. Ravichandran K, Al-Hamdan NA, Mohamed G. Knowledge, attitude, and behavior among Saudis toward cancer preventive practice. J Family Community Med 2010; 18(3): 135-42.
33. Temiz M, Asian A, Inandi T, Beshirov E, Beyaz F. Knowledge, Attitudes, and Behaviors of Female Teachers Related to Breast Cancer and Breast Examination in Southern Turkey. Breast Care (Basel) 2008; 3(1): 55-60.

34. Castro R. Câncer na mídia: uma questão de saúde pública. Rev Bras Cancerol 2009; 55(1): 41-8.

35. Kim JH, Menon U, Wang E, Szalacha L. Assess the effects of culturally relevant intervention on breast cancer knowledge, beliefs, and mammography use among Korean American women. J Immigr Minor Health 2009; 12(4): 586-97.

36. World Health Organization (WHO). Policy and Advocacy. Cancer control : knowledge into action : WHO guide for effective programmes. World Health Organization: 2007. Disponivel em: http://www.who.int/ cancer/FINAL-Advocacy-Module\%206.pdf. (Acessado em 03 de junho de 2009).

Received on: 06/26/12

Final version presented: 04/03/13

Accepted on: 06/05/13 